\title{
THE INFLUENCE OF PRODUCT INNOVATION AND LIFESTYLE ON PERCEIVED QUALITY AND INTEREST IN BUYING SONGKET
}

\author{
Kusumaningtiyas Retno* \\ Master's Program in Management, University of Mataram, Indonesia \\ Sulhaini, Rinuastuti Baiq Handayani \\ Faculty of Economics, University of Mataram, Indonesia \\ *E-mail: retnokusumaningtiyas@gmail.com
}

\begin{abstract}
This study aims to know and analyze the influence of product innovation and lifestyle on perceived quality, the influence of product innovation and lifestyle on buying interests as well as the influence of perceived quality on buying interest in Sukarara Songket, Central Lombok. Quantitative research with a causality approach which had a sample of 120 Art Shop visitors in Sukarara Village, West Nusa Tenggara, Indonesia. The sample criteria, which were at least 20 years old, came from outside Sukarara Village and prospective final customers (not resellers). The sampling technique used non probability sampling, namely purposive sampling technique. This study collecting data through interviews, questionnaires and observations. Data analysis techniques in this study used PLS (Partial Least Square) analysis with the SmartPLS software. The results showed that product innovation and lifestyle had an effect on perceived quality. Product innovation had no effect on buying interests. Lifestyle had an effect on buying interests and perceived quality had an effect on buying interests.
\end{abstract}

\section{KEY WORDS}

Product innovation, lifestyle, perceived quality, interest to buy, songket.

Product innovation has an influence on consumer buying interest (Ho and Wu, 2011). Product innovation is creating new products which can meet the needs and desires of consumers (Setiadi, 2003, in Suroso and Iriani, 2014). However, the results of this study were different from the results of research conducted by Ram and Seth (1989), they found that consumers would find it difficult or had the intention to make a purchase when a product innovates too often.

Lifestyle and perceived quality had an influence on buying interest and the majority of previous studies had stated that there was an influence between lifestyle and consumer buying interest (Dewi \& Soesanto, 2015; Fatharani et al., 2014; Liu et al, 2012). However, these results contradicted with studies by Saptoadi (2013) and Sari (2013) which proved that lifestyle did not affect consumers' buying interest.

The problem faced today is the weak ability of human resources, especially in terms of creativity and capability to innovate, thus impacting on weak competitive excellence and business performance (Sutapa, 2014). Songket as an ancestral heritage in Lombok in its development affects the acceptance of modern society because of unusual weaving attributes that can influence buying interests. Creativity and innovation in the creative industry are needed to be able to grow and compete; therefore creative entrepreneurs must be able to change the paradigm of culture in the context of performance-based art into performance-based entrepreneurship (Halim, 2011 in Sutapa, 2014).

During this time, previous research focused more on product innovation in large industrial sectors involving the latest technological sophistication, but still very limited to local businesses in the local area. Thus, this study aims to seek the effect of product innovation, lifestyle on perceived quality and interest in buying Sukarara Songket in Central Lombok, Indonesia. This study aims to analyze the product innovation on perceived quality, lifestyle 
on perceived quality, product innovation on buying interests, lifestyle on buying interests, perceived quality on buying interest in Sukarara songket, Central Lombok, Indonesia. This study is expected to be a scientific information to enrich the theory of the influence of product innovation, lifestyle on perceived quality and buying interest as well as input to SMEs (Small and medium-sized enterprises) on consumer behavior and policy holders as material for reviewing and evaluating business development in Songket centers.

\section{LITERATURE REVIEW}

According to Schiffman and Kanuk (2007), buying interest is interpreted as a form of mind that is evident from the reflection of the buyer's plan to buy several units in a certain number of brands available in a certain period of time. Factors that influence consumer buying interest include product innovation, lifestyle and perceived quality while buying interest indicators, that is looking for information about the store, prices and consumer shopping desire.

Product innovation according to Myers and Marquis (in Susanto, 2013), is a combination of various kinds of processes that influence each other. With the existence of product innovations carried out by the company, it is expected to increase purchasing decisions. Charles et al., (in Susanto, 2013) have stated that innovation is part of a framework that connects aspects of corporate culture with the ability to innovate and improve company performance through consumer buying decisions. The indicator of product innovation according to Saleksa and Firmansyah (2014) is the creation of new things in a product, product quality and product differentiation.

Lifestyle according to Engel \& Blackwall, 2005 (in Dewi \& Soesanto, 2015), it is defined as a pattern where people live and spend time and money. Lifestyle is a function of consumer motivation and prior learning, social class, demography, and other variables. Lifestyle is a summary conception that reflects consumer value. While Hawkins et al., (1998) have stated that a person's lifestyle influences the needs, behavior of his life and buying behavior. Lifestyle indicators according to Dewi \& Soesanto (2015) are practical lifestyles, luxurious lifestyles, investments and prestige.

Perceived Quality is the customer's perception of the quality or superiority of a product or service in terms of its relative function with other products (Simamora, 2002). Whereas according to Aaker (2003) in Salim and Dharmayanti (2014) suggest that perceived quality is a customer's perception of all the quality or superiority of a product or service in relation to the intended purpose. The indicators used are: Guarantee, Differentiation, Price, Product Line , Product innovation (Rianto \& Hendrawan, 2015; Holyet al., 2004).

Creative economic development is driven by capitalist creativity and innovation in producing products or services with creative content. Creative economy is a system of human activities related to the creation, production, distribution, exchange and consumption of valuable goods and services for market customers (Riadi, 2018).

The products are more innovative and have good quality that will be able to influence someone's buying interest, thus the hypotheses are formulated as follows:

Hypothesis 1: The more innovative Sukarara Songket products in Central Lombok, the higher perceived quality of consumers.

Hypothesis 2: The more innovative Sukarara Songket products in Central Lombok, the more it increases consumer buying interest.

Product innovation is one of the key factors in the success of some brands (VazquezBrust and Sarkis, 2012) innovation can improve product quality (Ottenbacher and Gnoth, 2005). Product innovation from a consumer's perspective is a new product that has a complex process and requires careful planning and costs or prices that are not cheap (Rusdi, 2016).

The perceived quality of a product is positively related to the extent to which products are distributed through shops with good images (Yoo, Donthu and Lee, 2000), with other products from the same category under different brands. Perceived quality as a customer evaluation on reliability, function, and customization (Walter et al., 2003). Product quality 
includes the attributes and features of a product that relies on its ability to satisfy and meet customer expectations (Yee and Sidek, 2008). Previous research conducted by (Prastyo \& Saino, 2013), product innovation indicators in this study were the new product that had never been made by another and it had a new function. Stating that product innovation had a partially significant influence on buying interest. Research from (Rahayu \& Anggarini, 2008; Suroso, 2014; Rusdi, 2016) proved the influence of product innovation on buying interest. Research by Indrayani and Nurcaya (2014) proved that perceived quality had a positive and significant effect on purchase intention.

Hypothesis 3: The more stylish individual, the higher the perceived quality of consumers toward Sukarara Songket in Central Lombok.

Lifestyle is a summary conception that reflects consumer value (Dewi \& Soesanto, 2015). While according to Simamora (2002), the perceived quality is the customer's perception of the quality or superiority of a product or service in terms of its relative function with other products. Lifestyle also affects consumers' perceptions when they want to make decisions, where perception does not only depend on physical stimulation, but also on stimuli related to the surrounding environment and the circumstances of the individual concerned. Consumer perceptions of the quality of a product can vary greatly between individuals with one another who experience the same reality. According to Kotler and Keller (2008) perceptions are more important than reality, because that perception will produce real consumer behavior. A study by Liu et al., (2010), lifestyle had a positive effect on the perception of product quality. Likewise with the research of Indrayani \& Nurcaya (2013), lifestyle had a positive effect on the perception of product quality.

Hypothesis 4: The more stylish the individual, the higher the consumer's buying interest in Sukarara Songket in Central Lombok.

Lifestyle according to Minor \& Mowen (in Dewi \& Soesanto, 2015), is to show how people live, how to spend money, and how to allocate time. Dewi \& Soesanto (2015), in a previous study showed lifestyle had a positive and significant effect on customer value and customer value had a positive and significant effect on consumer buying interest. A study from Rianto and Hendrawan (2015), lifestyle influenced simultaneously and partially on consumer purchasing decisions. Furthermore (Fatharani et al., 2013) found that lifestyle influenced buying interest. However, a study from (Saptoadi, 2013; Sari, 2013), proved that lifestyle did not affect consumers' buying interest.

Hypothesis 5: The higher the perceived quality, the higher the consumer's buying interest in Sukarara songket, Central Lombok.

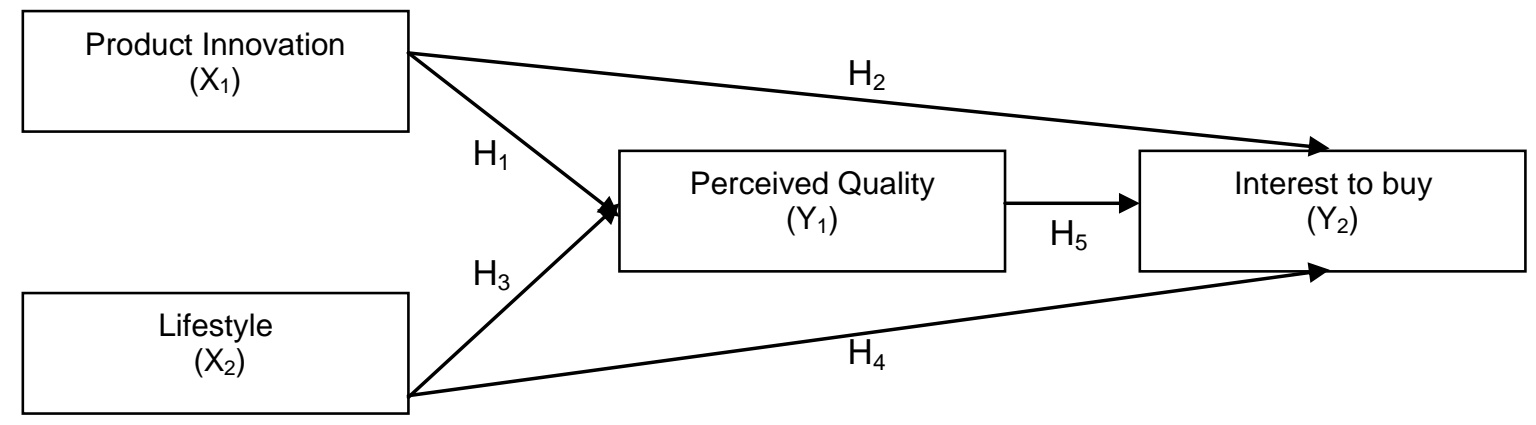

Figure 1 - Hypothesis Model

Chaudhuri and Holbrook (2002) have stated that the higher the quality perceived by consumers, the higher the purchase intention of consumers. Perceived quality is measured using four dimensions of Patrick (2002) in Arifin and Fachrodji (2016), namely dependence, reliability, excellence, and consistency, because these can be used to measure a consumer's overall assessment of a product or service.

A study from Arifin and Fachrodji (2016) found that perceived quality had an effect on consumers' purchase intention. Furthermore, Tsiotsou (2006) ( in Arifin and Fachrodji, 2016) proving that perceptions of quality and purchase intentions were directly positively correlated, 
so that perceived quality could be used in predicting purchase intentions. A study from Rianto and Hendrawan (2015) showed that perceived quality had the most dominant influence on consumer purchasing decisions. Research by Arifin and Fachrodji (2016) found that perceived quality influenced consumer buying interest. Further in study of Tsiotsou (2006) (in Arifin and Fachrodji, 2016) proving that perceptions of quality and purchase intentions were directly positively correlated, so that perceived quality could be used in predicting purchase intentions. A study from Rianto and Hendrawan (2015) showed that perceived quality had the most dominant influence on consumer purchasing decisions.

\section{METHODS OF RESEARCH}

Quantitative studies with a causality approach, have a population that is everyone who knows Sukarara Songket and the population in this study is infinitive (population was unknown). In this study the sampling method used was Purposive Sampling with samples chosen according to the criteria, namely Art Shop visitors who were in Sukarara Village, at least 20 years old, not the village society of Sukarara, and the final consumers (not resellers).

The location of this study is Naung Songket Art Shop in Sukarara, Central Lombok, West Nusa Tenggara, the total of samples of this study were based on the guidelines given by Roscoe (1975), where in each study the sample size should be between 30 - 500 (Rahayu, 2005). So that the sample was 120 people.

The indicator on the Product Innovation variable according to Saleksa (2014) is the creation of new things, product quality and product differentiation. Lifestyle variables according to Dewi \& Soesanto (2015) are practical lifestyles, luxurious lifestyles, investment and prestige. Perceived Quality variable according to Rianto \& Hendrawan (2015) and Holy et al., (2004), namely guarantee, differentiation, price and product line. Variable interest in buying according to Pujadi (2010) is to find the information about the store and price and the desire instantly to buy. The general description of respondents can be seen in the table below:

Table 1 - Overview of Respondents

\begin{tabular}{|c|c|c|c|}
\hline No. & Characteristics & Frequency (person) & Percentage (\%) \\
\hline \multirow{3}{*}{1.} & Gender: & & \\
\hline & - Male & 17 & 14.2 \\
\hline & - $\quad$ Female & 103 & 85.8 \\
\hline \multirow{5}{*}{2.} & Age: & & \\
\hline & - $\quad 20-30$ years old & 31 & 25.8 \\
\hline & - $\quad 31-40$ years old & 44 & 36.6 \\
\hline & - $\quad 41-50$ years old & 35 & 29.2 \\
\hline & $-\geq 51$ years old & 10 & 8.3 \\
\hline \multirow{5}{*}{3.} & Monthly Income: & & \\
\hline & - $\quad 2.5-<3.5$ millions & 69 & 57.5 \\
\hline & - $\quad 3.5<4.5$ millions & 19 & 15.8 \\
\hline & - $\quad 4.5<5.5$ millions & 16 & 13.3 \\
\hline & - $\quad \geq 5.5$ millions & 16 & 13.3 \\
\hline \multirow{4}{*}{4.} & Occupation: & & \\
\hline & - $\quad$ Private Employee & 46 & 38.3 \\
\hline & - $\quad$ Civil Servant & 27 & 22.5 \\
\hline & - $\quad$ Others & 47 & 39.2 \\
\hline
\end{tabular}

Based on the table above, respondents who had visited the art shop in Sukarara Central Lombok were dominated by women, this was mainly due to the support of appearance and came from the age group between 31-40 years with the characteristics of having maturity and being able to find a place in the community so that it required an appearance that matched the values of the social group. 
Respondents who had visited the art shop in Sukarara village, Central Lombok, were dominated by visitors with an income of $2.5<3.5$ millions IDR and included in the high income group, so that they had the financial advantage to purchase Sukarara Songket which had a relatively expensive, especially from other work groups.

In this study the data collection was carried out using a questionnaire. The measurement of this research variable was carried out using a data processing instrument namely the Likert scale, in weighting on each variable, each question / statement item provided a choice of answers with a scale range of 1-5. To make it easier for researchers to determine valid instruments, this research uses data processing using the SPSS program version 16. The data analysis technique used is Partial Least Square (PLS). Partial Least Square Analysis is a multivariate statistical technique that makes comparisons between multiple dependent variables and multiple independent variables by using SmartPLS software (Abdillah and Jogiyanto, 2015).

\section{RESULTS AND DISCUSSION}

Partial Least Square (PLS) analysis is used to test hypothesis. PLS does not assume a certain distribution for parameter estimates, so parametric techniques for testing significance are not needed. The PLS evaluation model is based on predictive measurements that have non-parametric properties. The measurement model (outer model) with reflective indicators is evaluated by convergent and discriminant validity from the indicator and composite reliability for the indicator block.

The linearity assumption test used to find out whether the model is obtained correctly in describing the relationship between variables so that it is categorized into a good or fit model. The basis of testing is the Curve Fit method which is calculated using SPSS software. The decision whether the relationship between these variables is linear using $p=5 \%$. The results of linearity test relationships between latent variables are presented in the following table:

Table 2 - Test Results for Linearity

\begin{tabular}{|l|c|c|}
\hline \multicolumn{1}{|c|}{ Relationship between variable } & Significance & Information \\
\hline Product Innovation $\rightarrow$ Perceived Quality & 0.000 & Linear \\
\hline Product Innovation $\rightarrow$ Interest to buy & 0.000 & Linear \\
\hline Lifestyle $\rightarrow$ Perceived Quality & 0.000 & Linear \\
\hline Lifestyle $\rightarrow$ Interest to buy & 0.000 & Linear \\
\hline Perceived Quality $\rightarrow$ Interest to buy & 0.000 & Linear \\
\hline
\end{tabular}

Source: SPSS analysis.

Can be seen in Table 2, that all forms of relationships between variables in the structural model are linear based on the level of significance smaller than 5 percent $(p<0.05)$. Thus the assumption of linearity on the structural model has been fulfilled. Referring to the criteria set by Hair et al., (1998) indicators that have a loading value of less than 0.3 will be dropped (removed) from the analysis. Thus in the construct of Product Innovation, Lifestyle, Perceived Quality and construct Intention to Buy, no indicator is dropped (removed) because all indicators have a loading value of more than 0.3 . This shows that all indicators used are valid. Convergent validity test results can be seen in the following table:

Table 3 - Outer Loadings (Measurement Model), CR, AVE and SL

\begin{tabular}{|c|c|c|c|c|}
\hline $\mathrm{n} / \mathrm{n}$ & AVE & $\mathrm{CR}$ & $(\lambda)$ & SL \\
\hline \multicolumn{5}{|l|}{ Product Innovation } \\
\hline I feel that Sukarara Songket has the latest motifs & \multirow{6}{*}{0.683} & \multirow{6}{*}{0.837} & 0.72 & .89 \\
\hline I feel that Sukarara Songket has a different design concept than before & & & 0.56 & .77 \\
\hline I feel that Sukarara Songket has better durability than before & & & 0.78 & .96 \\
\hline I feel that the making of Sukarara Songket is more thorough than before & & & 0.73 & .87 \\
\hline Sukarara Songket has its own uniqueness compared to others & & & 0.52 & .74 \\
\hline I feel that Sukarara Songket has a combination with new materials in its pr & & & 0.73 & .88 \\
\hline
\end{tabular}


Eurasia: Economics \& Business, 2(20), February 2019

DOI https://doi.org/10.18551/econeurasia.2019-02

\begin{tabular}{|c|c|c|c|c|}
\hline \multicolumn{5}{|l|}{ Lifestyle } \\
\hline Sukarara Songket is very easy and practical to use on every occasion. & \multirow{8}{*}{0.670} & \multirow{8}{*}{0.866} & 0.56 & .85 \\
\hline Using Sukarara Songket makes me look classy & & & 0.60 & .88 \\
\hline I often use Sukarara Songket on official events & & & 0.72 & .72 \\
\hline I bought Sukarara Songket to be invested in the future & & & 0.55 & .63 \\
\hline For me, using Sukarara Songket improves self-image. & & & 0.74 & .79 \\
\hline For me, using Sukarara Songket can improve my social status in the community & & & 0.75 & .64 \\
\hline I bought Sukarara Songket to get praise from others & & & 0.68 & .87 \\
\hline I feel that Sukarara Songket fits in me & & & 0.69 & .66 \\
\hline \multicolumn{5}{|l|}{ Perceived Quality } \\
\hline I feel that Sukarara Songket is durable and long lasting & \multirow{6}{*}{0.786} & \multirow{6}{*}{0.9307} & 0.79 & .87 \\
\hline $\begin{array}{l}\text { The sacrifices that I spent are proportional to the benefits of the product that I } \\
\text { receive. }\end{array}$ & & & 0.80 & .85 \\
\hline $\begin{array}{l}\text { I feel that the price for buying Sukarara Songket is not much different from my } \\
\text { previous estimate }\end{array}$ & & & 0.79 & .73 \\
\hline I think the price is reasonable when compared to other Songket & & & 0.78 & .78 \\
\hline There was no weaknesses found in Sukarara Songket when I was going to buy it & & & 0.80 & .82 \\
\hline $\begin{array}{l}\text { In my opinion, Sukarara Songket has a better quality compared to other Songket in } \\
\text { general }\end{array}$ & & & 0.74 & .76 \\
\hline \multicolumn{5}{|l|}{ Buying Interest } \\
\hline I seek for information on where to buy Sukarara Songket & \multirow{8}{*}{0.719} & \multirow{8}{*}{0.895} & 0.60 & .77 \\
\hline $\begin{array}{l}\text { I will look for information about Sukarara Songket from people who have bought it } \\
\text { before }\end{array}$ & & & 0.70 & 67 \\
\hline I am looking for the price of Sukarara Songket & & & 0.69 & .89 \\
\hline I will still buy Sukarara Songket even though other songket is cheaper & & & 0.81 & .74 \\
\hline $\begin{array}{l}\text { I will still buy Sukarara Songket even though it is not recommended by other } \\
\text { people }\end{array}$ & & & 0.71 & .73 \\
\hline I will still buy Sukarara Songket even though there are more interesting Songket & & & 0.75 & .66 \\
\hline I wish to immediately bu & & & 0.75 & .85 \\
\hline I would like to recommend Sukarara Songket to other peop & & & 0.69 & .89 \\
\hline
\end{tabular}

Source: SmartPLS analysis.

The research hypothesis test can be seen in table 4 . The table shows that only one hypothesis does not support while the other four hypotheses are supported by the data in this study.

Table 4 - The result of hypothesis examination

\begin{tabular}{lllll}
\hline $\mathrm{Nu}$. & Hypothesis & Path coeff. & t-statistic & Explanation \\
\hline $\mathrm{H} 1$ & Product Innovation $(\mathrm{X} 1) \rightarrow$ Perceived quality $(\mathrm{Y} 1)$ & 0.364 & 3.604 & Support \\
\hline $\mathrm{H} 2$ & Product innovation $(\mathrm{X} 1) \rightarrow$ Interest to buy $(\mathrm{Y} 2)$ & 0.012 & 0.133 & Not Support \\
\hline $\mathrm{H} 3$ & Lifestyle $(\mathrm{X} 2) \rightarrow$ Perceived quality $(\mathrm{Y} 1)$ & 0.516 & 5.506 & Support \\
\hline $\mathrm{H} 4$ & Lifestyle $(\mathrm{X} 2) \rightarrow$ Interest to buy $(\mathrm{Y} 2)$ & 0.617 & 5.859 & Support \\
\hline $\mathrm{H} 5$ & Perceived quality $(\mathrm{Y} 1) \rightarrow$ Interest to buy $(\mathrm{Y} 2)$ & 0.354 & 4.134 & Support \\
\hline
\end{tabular}

Source: SmartPLS analysis.

Hypothesis 1 indicated that the more innovative Sukarara Songket products in Central Lombok, the higher perceived quality of consumers. The test results on the parameter coefficient between product innovation and perceived quality indicated a positive influence with a coefficient value of 0.364 with a statistical $t$ value of 3.604 indicating a significant effect. The t-value is above the critical value 1,680 , thus Ha was accepted. This showed that innovation products had a positive and significant effect on perceived quality, meaning that the better innovation products would be able to increase the perceived quality of Sukarara Songket.

The results of this study confirmed that product innovation on motives, design concepts, uniqueness and use of new materials as well as having the durability and accuracy in the process would be able to improve the superiority of the products. The results of this study were in line with the research conducted by Kirmani and Rao (2000) who found that innovation products had a positive and significant influence on percieved quality and the 
study conducted by Shiau (2014) had indicated that product innovation was the main consideration factor affecting consumers in making a purchase.

The findings of this study illustrated that when innovation in a product was present, the perception of the quality of the product would increase. This was because the Sukarara Songket are durable and has better quality and prices that are comparable to the manufacturing process. Innovation is part of a framework that connects the cultural aspects of a business so that the ability of a company or business to continue to innovate on its products will enhance consumer perceptions of the quality of the product. When the product is quickly updated, this indicates that the product is well managed by the company and this will increase the perception or response of consumers that the product has good quality because it continues to improve its capabilities.

Hypothesis 2 indicated that the more innovative Sukarara Songket in Central Lombok further would increase consumer buying interest. The test results on the parameter coefficient between product innovation and buying interest showed a positive influence with a coefficient value of 0.012 and a statistical $t$ value of 0.013 indicating that the effect was not significant. The t-value of the statistic was below the critical value of 1.680 , thus Ha was rejected. This showed that product innovation had no influence on buying interest.

The results of this study were in line with the study conducted by Ram and Seth (1989) who found that product innovation had no influence on buying interest. The results of this study proved and confirmed that customers or individuals who would buy Sukarara songket cloth did not want innovation products because this might reduce the authenticity of Sukarara Songket. Sukarara Songket is highly maintained its authenticity. This authenticity makes Sukarara Songket has its own uniqueness and sought after by many people.

Hypothesis 3 showed that the more stylish individuals, the higher the perceived quality of consumers towards Sukarara Songket in Central Lombok. The test results of the lifestyle coefficient parameter on perceived quality indicated a positive influence with a coefficient value of 0.516 and a statistic $t$ value of 5.506 showed a significant effect. The t-value of the statistic was above the critical value of 1.680 , thus Ha was accepted. This showed that lifestyle had a positive and significant effect on perceived quality, meaning that the more stylish an individual would increase their perceived quality of a product.

The results of this study were in line with the research conducted by Liu et al., (2012) that lifestyle had a positive effect on the perception of product quality. Likewise with the research of Indrayani \& Nurcaya (2013) lifestyle had a positive effect on the perception of product quality. These indicated that lifestyle had an influence on perceived quality. This happened because lifestyle was not only limited to social class but interests and opinions or perceptions. So, the more stylish a person would be the more perceptions of quality would be better. The individual had his own preferences when choosing a product, based on the results of this study, stylish individuals would have their own class of opinions related to the quality of the product. Stylish individuals were individuals who think of every detail of the product they wear. Thus, this study proved that stylish individuals would choose products which had good quality so that their perceptions of quality were an important concern.

Hypothesis 4 showed that the more stylish the individual, the higher consumer's buying interest in Sukarara Songket in Central Lombok. The test results of the lifestyle coefficient parameter on buying interest indicate a positive influence with a coefficient value of 0.617 and a statistical $t$ value of 5.859 shows a significant effect. The $t$-value of the statistic is above the critical value of 1.680 , thus $\mathrm{Ha}$ is accepted. This shows that lifestyle has a positive and significant effect on buying interest, meaning that the more stylish an individual will increase the buying interest in Sukarara songket.

The results of this study proved that Sukarara Songket was one of the choices for people who were stylish because the more stylish the individual, the higher their interest in buying Sukarara Songket. The buying intention that arised in consumers must be based on their lifestyle. This is because lifestyle is a person's pattern in the world that is revealed in his activities, interests and opinions (Kotler and Keller, 2008). So, lifestyle greatly affects someone to buy and own a product and service. The results of this study supported the 
results of a study conducted by Suraputra and Warmika (2017) who found that lifestyle had a positive and significant influence on buying interest.

Hypothesis 5 showed that the higher perceived quality, the higher the consumer's buying interest toward Sukarara songket in Central Lombok. The results of the perceived quality coefficient parameter on buying interest indicated a positive influence with a coefficient value of 0.354 and the statistical t-value of 4.134 showed a significant effect. The $\mathrm{t}$-value of the statistic is above the critical value of 1.680 , thus $\mathrm{Ha}$ is accepted. This showed that perceived quality had a positive and significant effect on interest buying, meaning that perceived quality influences the interest in buying Sukarara songket.

The results of this study in accordance with the research by Arifin and Fachrodji (2016) found that perceived quality affects buying interest. The results of this study also prove that the perceived quality has an influence on buying interest in Sukarara songket. Because Sukarara songket has certain known quality standards. Sukarara Songket is a ancestral heritage fabric that has its own standard of work so that the perceived quality of a consumer will affect their interest in buying Sukarara songket. Customers previously knew the quality of the Sukarara songket, so they had own mindset of the perception of the quality of Sukarara songket which cannot be duplicated in other areas.

The influence of Product Innovation on Buying Interest through Perceived Quality. Based on the results of data analysis, from these calculations, there was an indirect effect between product innovation variables and buying interest through perceived quality with a path coefficient value of 0.04 . Comparison of indirect innovation of product innovation with buying interest through perceived quality with direct effect between product innovation on buying interest is $0.128>0.012$ so that it could be stated that perceived quality functions as full mediation in the influence of product innovation on buying interest in Sukarara Songket.

Moreover, based on the results of this study, innovation products had no effect on buying interest. Thus, the perception of quality was very important to mediate the relationship of innovation products to buying interest. Product innovation that was too fast would make it difficult for consumers to re-adapt to the product, besides, that product innovation would make some existing products changed and this would make consumers not interested in buying the product. Even this happened to Sukarara Songket, existing product innovation would make consumers reluctant to buy, but if there is a perception of good quality from consumers, consumers would consider to buy Sukarara Songket.

The Influence of Lifestyle on Buying Interest through Perceived Quality. Based on the results of data analysis, from the calculations, there was an indirect influence between lifestyle variables and buying interest through perceived quality with a path coefficient value of 0.057. Comparison of indirect effects of lifestyle and buying interest through perceived quality with its direct influence between lifestyle and buying interest was $0.182>0.057$ so that it could be stated that perceived quality functions as full mediation in the influence of lifestyle on the interest in buying Sukarara Songket.

The results of this study proved that when a person was more stylish they would pay attention to the details of the condition of a product. When all of these sensing results had been in the perception of the consumer, the perception of the quality of the product would be created. In Sukarara Songket, consumers already knew the quality of the product so that they would more easily had the intention to buy Sukarara Songket. The finding also illustrated that perceived quality would be one of the key variables between lifestyle relationships and buying interest. Even though someone was stylish they would still pay attention to the quality of the product they bought so that the perception of the positive quality of the Sukarara Songket was very important to maintain and even improved.

\section{CONCLUSION}

Based on the data analysis, it can be concluded as follows:

1. Product Innovation affected the Perceived Quality. This showed that the better innovation of the product would increase the perceived quality of the respondents; 
2. Lifestyle affected the Perceived Quality. This showed that the better the stylish person would increase the perceived quality of Sukarara Songket;

3. Product Innovation had a partial effect on buying interests. This showed that product innovation did not always make someone interested in buying Sukarara Songket. This finding illustrated that product innovation in Sukarara Songket was not always influence buying interest;

4. Lifestyle had an effect on buying interest. This showed that the more stylish a person would increase the buying interest in Sukarara Songket;

5. Perceived Quality had an effect on buying interest. This is because Sukarara Songket had certain standards that had been known before. Sukarara Songket is a hereditary heritage fabric that has its own standard of work so that the perception of the quality of a consumer would affect their interest in buying Sukarara Songket.

Managerial Implications. For the government, it is expected to have a leading role in the form of guidance and assistance to be able to encourage the growth of innovative ideas for the creative industries of Sukarara Songket without leaving a genuine hereditary heritage that must be kept authentic but adapted to changing consumer needs and desires. For businessmen, the success of the creative industry in the Sukarara weaving center is determined by the ability to innovate products and segment the market for the realization of a strong creative industry.

Limitations and Suggestions for Further Research. This study only examines product innovation and lifestyle variables as independent variables with mediated perceived quality variables, whereas there are still many other variables that cause buying interest both as independent variables and mediating variables, so that further researchers need to add trust variables, prices and promotions. This research also focuses only on art shop visitors, whereas in fact, so many people know about Sukarara Songket outside of art shop visitors, thus limiting the generalization of the findings.

For further research, researchers can examine people outside the art shop or tourists who have bought Sukarara songket cloth so that the results obtained are more accurate and use more samples so the results can be more generalized.

\section{REFERENCES}

1. Abdillah, W., \& Jogiyanto. (2015). Partial Least Square (PLS) Alternatif Structural Equation Modelling (SEM) dalam Penelitian Bisnis. Ed.1. Yogyakarta: Andi.

2. Arifin, E., \& Fachrodji, A. (2015). Pengaruh Persepsi Kualitas Produk, Citra Merek and Promosi Terhadap Minat Beli Konsumen Ban Achilles di Jakarta Selatan. Jurnal MIX, 5 (1), 124-143.

3. Chaudhuri, A., \& Holbrook, M.B. (2001). The Chain of Effect from Brand Trust and Affect to Brand Performance: The Role of Brand Loyalty. Journal of Marketing, 65 (2), 81-93.

4. Dewi, A.A., \& Soesanto, H. (2015). Analisis Pengaruh Life Style, Kualitas Pelayanan and Perceived Value Terhadap Customer Value Untuk Meningkatkan Minat Beli Konsumen Pada Apartemen Di Semarang (Studi Pada Mg. Suites Apartemen, Star Apartemen and the Parama Graha Apartemen). Diponegoro Journal of Management, 4 (2), 1-13.

5. Fatharani, A., Lubis, N., \& Dewi, R.S. (2013). Pengaruh gaya hidup (life style), harga (price) and kelompok referensi (Reference Group) terhadap keputusan pembelian telepon selular blackberry (studi pada mahasiswa program S1 Angkatan 2009 Fakultas IImu Sosial and IImu Politik Universitas Diponegoro). Jurnal IImu Administrasi Bisnis 2 (3), 1-20.

6. Indrayani, L., \& Nurcaya, I.N. (2014). Peran Persepsi Kualitas Produk dalam Memediasi Pengaruh Gaya Hidup Terhadap Niat Beli Handphone Samsung Galaxy di Kota Denpasar. E-Jurnal Manajemen Universitas Udayana, 3 (4), 1-17.

7. Hair, JF., Anderson, R.E., Tatham, R.L., \& Black. W.C. (1998). Multivariate Data Analysis, $5^{\text {th }}$ Edition. New Jersey. Prentice Hall.

8. Hawkins, I Del., Best, J. R., \& Coney, K. A. (1998). Consumer Behavior: Building Marketing Strategy. Boston. Irwin/Mc Graw Hill. 
9. Ho, Cheng-Hsun., \& Wu, Wenchieh. (2011). Role of Innovativeness of Consumer in Relationship Between Perceived Atrributes of New Product and Intention to Adopt. International Journal of Electronic Business Management, 9 (3), 258-266.

10. Holy Y. I., Sugiarto, D.D., \& Sitinjak, T. (2004). Model Matrik Konsumen Untuk Menciptakan Superior Customer Value. Jakarta. PT. GramediaPustaka Utama.

11. Kirmani, A., \& Rao, A. (2000). No Pain, No Gain; A Critical Review of The Literature on Signaling Unobservable Product Quality. Journal of Marketing, 64 (2), 66-79.

12. Kotler, P., \& Keller, K.L. (2008). Manajemen Pemasaran, Jilid 1. Penerbit Erlangga. Jakarta.

13. Liu, Weining, Chang, LY., \& Lin, JR. (2012). Consumer Lifestyle Matters; Evidence From Gray Markets in China. Journal of Services Science and Management, 5, 196-205. DOI: 10.4236/jssm.2012.52024.

14. Ottenbacher, M.C., \& Gnoth, J. (2005). How to develop successful Hospitality innovation. Cornell Hotel and Restaurant Administration Quarterly, 46 (2), 205-22. DOI: 10.1177/0010880404271097.

15. Prastyo, D., \& Saino. (2013). Pengaruh Inovasi and Kualitas Produk Terhadap Minat Beli Yoga Tablet Lenovo Di Surabaya. Program Studi Pendidikan Tata Niaga, Jurusan Pendidikan Ekonomi. Fakultas Ekonomi Universitas Negeri Surabaya.

16. Pujadi, B. (2010). Studi tentang pengaruh citra merek terhadap minat beli melalui sikap terhadap merek (Kasus pada merek pasta gigi ciptadent di Semarang) .Tesis. Universitas Diponegoro. Semarang.

17. Rahayu, A., \& Anggarini, G. (2009). Pengaruh Inovasi Produk terhadap Keputusan Pembelian Produk Audio Sony (survei pada Konsumen di Toko Aneka Irama Jalan ABC Bandung). Jurnal of Business Management \& Entrepreneur Education, 8 (16), 12-29.

18. Rahayu, S. (2005). SPSS Versi 12.00 Dalam Riset Pemasaran. Bandung. CV Alfabeta.

19. Ram, S., \& Sheth, J.N. (1989). Consumer Resistance to Innovation: The Marketing Problem and Its Solution. Journal of Consumer Marketing, 6 (2) Spring, 5-14.

20. Riadi, M. (2018). Pengertian, ciri-ciri dari sektor ekonomi atau industri. Kajian Pustaka.com.

21. Rianto, C.A., \& Hendrawan, D. (2015). Pengaruh Gaya Hidup and Persepsi Kualitas terhadap Keputusan Pembelian Produk Peter Says Denim di Kota Malang. Jurnal IImiah Mahasiswa FEB, 2 (2).

22. Roscoe, J.T. (1975). Fundamental Research Statistics for the Behavioural Sciences. (2nd ed.) New York: Holt Rinehart \& Winston.

23. Rusdi. (2016). Pengaruh Inovasi Produk and Harga Terhadap Minat Beli All New Yaris (Studi Di Toyota Auto 2000 waru Sidoarjo). Jurnal Ilmu Manajemen, 4 (3).

24. Saleksa, G.R., \& Firmansyah, A. (2014). Pengaruh Innovation terhadap Firm Performance pada UMKM Meubel di Kabupaten Bojonegoro. Jurnal Manajemen Teori and Terapan, 7 (3).

25. Salim, F. F., \& Dharmayanti, D. (2014). Pengaruh Brand Image and Perceived Quality terhadap kepuasan and loyalitas pelanggan mobil toyota di Surabaya. Jurnal Manajemen Pemasaran Petra, 2 (1), 1-8.

26. Saptoadi. (2013). Pengaruh Gaya Hidup and Kualitas Produk Terhadap Minat Beli Honda Vario Techno 125 PGM-F1. Program Studi Manajemen, Jurusan Manajemen. Fakultas Ekonomi, Universitas Sanata Dharma Yogyakarta

27. Sari, D.R. (2013). Pengaruh Gaya Hidup and Nilai Terhadap Minat Beli Produk Day Cream Rumput Laut. Departemen IImu Keluarga and Konsumen, Fakultas Ekologi Manusia. Institut Pertanian Bogor.

28. Schiffman, L.G., \& Kanuk, L.L. (2007). Perilaku Konsumen Edisi ke-7. Diterjemahkan oleh Zoelkifli Kasip. Jakarta. PT Indeks.

29. Shiau, H.C. (2014). The Impact of Product Innovation on Behavior Intention: The Measurement of the Mediating Effect of the Brand Image of Japanese Anime Dolls. Anthropologist, 17(3), 777-788.

30. Simamora, B. (2002). Aura Merek: Tujuh Jurus Membangun Merek yang kuat. Jurnal Ekonomi Perusahaan, 9 (2), 233-268. 
31. Suraputra, I.M.W., \& Warmika, I.G.K. (2017). Pengaruh Gaya Hidup terhadap Niat Pembelian Sepeda Motor Sport Honda yang dimediasi oleh sikap. E-hurnal Manajemen UNUD, 6 (1), 176-203. ISSN: 2302-8912.

32. Suroso, H. B. (2014). Pengaruh Inovasi Produk and Harga Terhadap Minat Beli Mie Sedap Cup. Jurnal IImu Manajemen, 2 (4).

33. Susanto, A. (2013). Pengaruh Promosi, Harga and Inovasi Produk Terhadap Keputusan Pembelian Pada Batik Tulis Karang Melati Demak. Jurusan Manajemen Fakultass Ekonomi Universitas Negeri Semarang.

34. Sutapa, M. (2014). Peningkatan kapabilitas inovasi, keunggulan bersaing and kinerja melalui pendekatan quadruple helix: studi pada industri kreatif sektor fashion. Jurnal Manajemen Teknologi, 13(3).

35. Vazquez-Brust, D. A., \& Sarkis, J. (2012). Green Growth: Managing the transition to sustainable economy. Futures 64, 38-50. DOI:10.1016/j.futures.2014.10.00.

36. Walter, A., Muller, T.A., Helfert, G., \& Ritter, T. (2003). Functions of Industrial Supplier Relationships and Their Impact on Relationship Quality. Industrial Marketing Management, 32 (2), 159-169. DOI: 10.1016/S0019-8501(02)00230-4.

37. Yee, W.F., \& Sidek, Y. (2008). Influence of Brand Loyalty on Consumer Sportwear. International Journal of Economics and Management, 2 (2), 221-236.

38. Yoo, B., Donthu, N. and Lee, S. (2000). An Examination of Selected Marketing Mix Elements and Brand Equity. Journal of the Academy of Marketing Science, 28, 195-211. https://doi.org/10.1177/0092070300282002. 